\title{
Article \\ Bidding Better Online in Belgium: The Value of Auction House Expertise during the COVID-19 Pandemic
}

\author{
Syra Kalbermatten and Christoph Rausch *
}

check for updates

Citation: Kalbermatten, Syra, and Christoph Rausch. 2021. Bidding Better Online in Belgium: The Value of Auction House Expertise during the COVID-19 Pandemic. Arts 10: 75. https://doi.org/10.3390/ arts10040075

Academic Editor: Elena Sidorova

Received: 31 August 2021

Accepted: 31 August 2021

Published: 5 November 2021

Publisher's Note: MDPI stays neutral with regard to jurisdictional claims in published maps and institutional affiliations.

Copyright: (c) 2021 by the authors. Licensee MDPI, Basel, Switzerland. This article is an open access article distributed under the terms and conditions of the Creative Commons Attribution (CC BY) license (https:// creativecommons.org/licenses/by/ $4.0 /)$.
Faculty of Science and Engineering, Maastricht University, 6211 LK Maastricht, The Netherlands; s.kalbermatten@alumni.maastrichtuniversity.nl

* Correspondence: christoph.rausch@maastrichtuniversity.nl

\begin{abstract}
In this article, we present our analysis of how one of Belgium's largest auction houses has creatively dealt with the forced transition to online auctions during the COVID-19 pandemic. Based on in-depth qualitative interviews and participant observation conducted at Bernaerts Auctioneers in Antwerp over a period of three months between February and April 2021, we show how the auction house has succeeded at maintaining relations with its clients and the public while exclusively moving its sales online. Our specific focus was on the mediation of expertise. Drawing on recent publications from the fields of economic sociology and anthropology, we analyzed how expert narratives of origin, authenticity, and uniqueness are communicated online to affect an object's auction value. Based on our empirical research, which also includes narrative analyses of Bernaerts Auctioneers' internet publication Prelude, as well as content shared online via social media, we argue that expert knowledge and practices of expertise are resilient and-contrary to what neoclassical economic theory might suggest - that they continue to be central to negotiations of value, as well as in online auctions.
\end{abstract}

Keywords: online auctions; online art market; COVID-19 pandemic; expertise; value

\section{Introduction}

On 29 June 2020, when the COVID-19 pandemic was at its preliminary worst, Francis Bacon's 1981 Triptych Inspired by the Oresteia of Aeschylus sold for a record-breaking value of USD 84,550,000 in an online auction. Bidders from around the world participated in what Sotheby's had advertised as a "multi-camera, global livestream" event, resulting in the most expensive work sold in 2020 (Sotheby's n.d.; Mun-Desalle 2020). Since the 1990s, the art market has been undergoing a slow but steady digital transformation, with the online auction market growing into a full-fledged market segment (Adam 2014; Pownall 2017; Sidorova 2019). Thus, when the pandemic effectively threw the entire world into lockdown, auction houses were in a good position to improvise, and they quickly abandoned what was left of any initial reticence to sell art digitally. According to ARTnews, the global health crisis saw major players like Sotheby's and Christie's "swiftly adapt their marquee evening auctions for a new era, ushering in live-streamed hybrid mega-sales that saw a host of masterpiece-level works reach staggering prices" (Villa 2020). However, although many auction houses were already working with variable hybrid formats when the pandemic hit, the complete switch to online auctions overnight brought with it some difficulties, and it continues to test the creativity and resilience of the auction market.

In this article, we take a closer look at how Bernaerts Auctioneers in Antwerp creatively deals with the forced transition to online auctions. Based on in-depth qualitative interviews and participant observation conducted at Bernaerts Auctioneers over a period of three months between February and April 2021, we mapped the consequences of the COVID19 pandemic for one of Belgium's largest auction houses. Considering that Bernaerts Auctioneers' marketing slogan is "Better in Belgium", we show how the auction house has succeeded at maintaining relations with its clients and the public while exclusively moving its sales online. Our specific focus was on the mediation of expertise. Drawing on 
recent publications from the fields of economic sociology and anthropology, we analyzed how expert narratives of origin, authenticity, and uniqueness are communicated online to affect an object's auction value. Based on our empirical research, which also included narrative analyses of Bernaerts Auctioneers' internet publication Prelude, as well as content shared online via social media, we argue that expert knowledge and practices of expertise are resilient and — contrary to what neoclassical economic theory might suggest-that they continue to be central to negotiations of value, as well as in online auctions.

\section{Three Decades of Auctioning Art Online}

In the pre-COVID era, it was striking that the shares of online sales at the second-and third-tier auction houses were significantly higher (18\% in 2019) than at their top-tier peers (McAndrew 2020). According to Rachel Pownall, the diverse offerings of these auction houses (often including memorabilia and collectibles), as well as the lower financial risk within that segment contributed to this difference (2017). In addition, the online art market initially did not appear to accommodate the needs of high-end collectors well enough. For example, the essential trusting relationship these buyers were looking for prior to their purchase was traditionally sought through live and in-person interactions with a dealer or auction house expert (p. 28). Finally, buying art is very much about the experience. As Georgina Adam notes, apparently the pleasure that comes with visiting art fairs abroad and the testosterone-fueled excitement hanging in the air in the auction room during a bidding battle cannot yet be replaced by a virtual surrogate (Adam 2014, p. 128).

Nevertheless, the growth of the online art market has been steady, peaking in 2018 and plateauing right before the COVID-19 pandemic in 2019. According to the Art Basel $\mathcal{E}$ UBS Art Market Report, the online art market comprised 5\% of the total art market in 2013, with its volume estimated at $\$ 3.1$ billion. In 2018, the segment was estimated at $\$ 6$ billion, with its share of the total market volume having risen to $9 \%$ - a share that remained stable in 2019 (McAndrew 2020). The Hiscox Online Trade Report reached a similar conclusion (Hiscox 2021, p. 4). Apparently, the online art market had evolved into a stable component of the global art market, though it did not exactly seem to be likely to dominate the offline scene soon-until the global pandemic changed things.

In fact, when the pandemic hit in early 2020, many auction houses had already been working with a hybrid format of auctioneering. These auction houses quickly adapted their practices and switched to fully online, live-streamed sales that took place in front of an empty room as if it were full. According to the New York Times, auction houses tried "to make sure selling their high-ticket objects doesn't devolve into an eBay frenzy, where wealthy buyers are sitting around in their pajamas stalking deals on their laptops" (Sullivan 2020). Rather, auction houses did everything they could to bring the excitement and sensation of live auctioneering into the homes of the bidders, and they seemed to do this surprisingly well.

When taking a closer look at the figures, it became clear that 2020 was an extremely positive year for the online auction market, with a record turnover of $\$ 12.4$ billion (McAndrew 2021, p. 17). Perhaps unsurprisingly, due to the restrictions posed by the pandemic, the market share accounted for $25 \%$ of the global art market in 2020, up from $9 \%$ in 2019. Notably, the willingness to buy art online increased, especially among millennials; "high-spending art buyers" also found their way to the online market, if only out of necessity (McAndrew 2021). Furthermore, the ArtPrice report noted that the number of online auctions in the high-end segment rose by a colossal $262 \%$ for Christie's and by a staggering $440 \%$ for Sotheby's (ArtPrice 2021, p. 15).

The current success of the online art auction market is not exclusively due to the adaptability of the auction houses, but was helped also by the macro-economic context informed by the lax monetary policy of the years following the 2007-2008 global financial crisis (see e.g., Adkins et al. 2020). Buyers are resorting to art as an alternative form of investment or speculation - be it to diversify their portfolio of assets for fear of inflation, to avoid or evade taxes, and even for criminal money laundering purposes (Adam 2018; 
Rausch et al. 2021). In other words, during the COVID-19 pandemic, there have been strong incentives for buyers to continue to acquire artworks, no matter the auction format. Nonetheless, to effectively play into this favorable context under the restrictions caused by the pandemic and to make the switch to online auctions work, auction houses had to become increasingly creative in opening alternative channels of communication.

How exactly do auction houses maintain their relationship with the public when their sales have to take place behind closed doors? What role does the expertise of art experts and auctioneers play in online auctions? To answer these questions, we first focused on the situation at Bernaerts Auctioneers in Antwerp before and after the COVID-19 pandemic, reflecting on the impact of the "corona crisis" on their regular operations. In this paper, we highlight the extra efforts the auction house has made to maintain its relationship with its client base and audience, and we discuss how Bernaerts Auctioneers uses alternative forms of mediation to bring its expertise to potential bidders.

\section{Adapting to the Challenges of the COVID-19 Pandemic}

Within the densely populated Belgian art market, Bernaerts Auctioneers is one of the leading auction houses. In terms of online presence, this auction house was an early pioneer. For example, Bernaerts Auctioneers' first website was up and running already in 1996 (P. Bernaerts and C. Bernaerts, personal communication, 1 April 2021). In addition, they were the first auction house in Belgium to integrate methods of bidding via the internet. Having started with timed online auctions in 2010, in 2011, Bernaerts started live online auctions, during which bidding can take place in the hall, by telephone, via purchase order, or online.

Bernaerts Auctioneers' first technological cooperation for this was with the American company NextLot, for which Bernaerts fulfilled a demo role, as NextLot hoped to attract other Belgian auction houses. In 2019, however, Bernaerts Auctioneers switched to Auction Mobility, white-label software that presents itself as a competitor to Invaluable (the top platform to date) due to its suitability for mobile devices. Using Auction Mobility's software, Bernaerts Auctioneers has now set up its own online platform under the URL https: / / live.bernaerts.eu (accessed on 31 August 2021). Via this website, customers can bid online during the auction, buy at an after-sale, or submit their pre-bids online. In addition, Bernaerts Auctioneers remains present on Invaluable and utilizes Drouotonline, platforms functioning as alternative auction marketplaces online. Taken together, these initiatives led to Bernaerts Auctioneers selling an average of $12-17 \%$ of their annual sales online before the COVID-19 pandemic.

Then, in March 2020 the art market was almost completely paralyzed by the first lockdown. When, for sanitary reasons, the public was no longer allowed in the auction rooms, initially, most of the Belgian auction houses effectively stopped offering their services. According to Peter Bernaerts, the co-owner of Bernaerts Auctioneers together with his brother Christophe Bernaerts, there were multiple reasons for this. According to Peter Bernaerts, it was a combination of the lack of exhibition possibilities, the perceived lack of the right tools, as well as a fear of failure that caused the majority of the national auction houses to cease their operations. Peter and Christophe Bernaerts had long debated whether or not to take the plunge and organize a complete online auction "live in an empty room", without a prior exhibition. One of the decisive factors to try it now, in the face of the COVID-19 pandemic, was the already existing functionality of their fully operational online platform.

The brothers Bernaerts wanted to guarantee continuity within their operations. They did not want to let buyers and sellers down. In addition, they were acutely aware that if all auctions in Belgium were postponed until "after corona", they would end up in a "bottleneck" situation with other auction houses, resulting in scheduling conflicts and an oversupply of art, resulting in lower prices. To reduce the risk of "burning" lots-the failure to sell, resulting in a significant reduction in future sales opportunities-Christophe Bernaerts explained that in May 2020, they held a smaller auction than usual, with fewer 
offerings. Due to the restrictive measures, this sale was conducted entirely on the basis of photographs; nobody was able to see the work before buying it and the auction house hoped to build on their own already existing customer base and reputation.

To compensate for the lack of (or limited forms of) exhibition possibilities and to maintain their relationship with their clients and the public, Bernaerts Auctioneers went to great lengths to continue to bring expertise to its potential customers. Although the auction house temporarily stopped printing traditional catalogs, as there was no longer any need for this due to the lack of exhibitions, they did start up an online magazine entitled Prelude, in which the top pieces of their auctions are highlighted. In addition, extra effort was put into the use of social media, and an additional staff member was hired to take care of Bernaerts Auctioneers' online channels. Besides messages with text and explanations, the auction house also posted videos in which knowledgeable experts explain a particular work from the auction.

The auction house installed a chat function on its website, claiming that the threshold for sending a chat message is lower than for sending an e-mail, as customers get an immediate answer from an expert. Moreover, Bernaerts Auctioneers began to invest more in its targeted online marketing; for example, it sent customers deemed specifically interested in a particular artist or a particular type of work a personal e-mail to inform them that a potentially interesting piece was included in the auction. According to Christoph Bernaerts, the response was generally positive; he believes that people felt honored and appreciated that they were being considered personally. At a time when there was absolutely no possibility of exhibiting on site, the intermediation of expertise via social media appeared to work as a surrogate for a different kind of social interaction.

\section{Value and Expertise in a Market of Singularities}

In Auctions: The Social Construction of Value, the economic sociologist Charles Smith (1989) describes auctions as "social processes for establishing socially acceptable definitions of value and ownership" (p. ix). Based on empirical research and sociological theory, Smith explains that traditions, values, and norms play a significant role in the auction room (p. 4). According to his analysis and contrary to the orthodox economics of supply and demand, bidders are not driven purely by individual, rational interests, but collectively engage in resolving issues concerning the price and allocation of objects. For Smith, these dynamics ensure the reproduction of collective definitions of value (p. 4). According to him, actual auctions, contrary to what some neoclassical economic models might suggest, are not exclusively or even primarily exchange processes. Rather, they are practices of managing the ambiguity and uncertainty of value by creating meaning and consensus (p. 163). As such, auctions are always influenced by social and personal constraints, such as preferences, opinions, rules, habits, and institutionalized practices (p. 175).

Similar to Smith, the economist André Orleans argues against neoclassical economics, its suggestion that value is intrinsic to objects, and that their supply and demand determines the fluctuation of prices. In The Empire of Value: A New Foundation for Economics, Orleans argues that "market value is an autonomous phenomenon that cannot be reduced to any preexisting magnitude such as utility, labour or scarcity" (Orléans 2014, p. 4). Rather, Orléans calls for the dissociation of value and price and proposes to approach exchange value as a social institution. This is essentially what the economic sociologist anthropologist Lucien Karpik does in "Valuing the Unique: The Economics of Singularities" (Karpik 2010).

According to Karpik, neoclassical economics structurally overlooks a certain category of markets (Karpik 2010, p. 3). According to him, this is a logical consequence of theories that, in their pursuit of universalism, use a definition of exchange goods and services in which price is seen as the only differential characteristic (p. 4). Other types of values and alternative ways of measuring (so-called "calculating devices") find no place in these theories. Instead, Karpik argues, they gradually convert qualities into quantities, which is why the world they describe "becomes more homogenous, more impersonal, and more of 
a threat to the aesthetic, sensitive and moral richness of humankind" (p. 7). According to Karpik, this results in a blind spot, which is what he calls the "market of singularities".

Karpik defines singularities, which include works of art, as objects and services that are part of our daily lives and which have three distinguishing characteristics-they are multidimensional, characterized by uncertainty, and are incomparable (p. 10). For Karpik, uncertainty about the quality of these services and objects is the main factor that excludes singularities from a traditional economic vision of supply and demand as determining their price. In a "market of singularities", the quality of an object or service is often only partially known at the moment of purchase. It usually takes some time to arrive at a realistic assessment of the quality, or-under circumstances of radical uncertainty-a definitive assessment can never be reached (p. 12).

According to Karpik, because of the multidimensionality and diversity of consumer preferences, a "spontaneous and happy encounter between supply and demand" is extremely rare in a market of singularities (p. 14). Often the search for quality prevails over price competition and, consequently, there is a need for a variety of "coordination devices" that assist the consumer in making choices. For example, in the case of art, the search for the "right" artwork is rarely reduced to the cheapest work, which is why knowledge of and expertise about the art market is imperative. In fact, buyers of art consult both "personal and impersonal judgement devices" to decide on purchases, and the effectiveness of these devices depends mostly on the credibility attached to them. Ultimately, then, it is reliable and trustworthy expertise that is needed to determine the quality and to reduce uncertainty regarding the pricing of art (p. 134) (also compare Bonus and Ronte 1997; Velthuis 2007, 2011; Arora and Vermeylen 2012, p. 4; Beckert and Rossel 2013).

Indeed, according to the sociologist Olav Velthuis, the prices of artworks are themselves embedded into the structures of meaning governing the art market, in the preexisting institutional frameworks of this market, and in the shared norms and values of the agents who populate it (Velthuis 2011). In this context, the role of experts can perhaps best be conceptualized as "gatekeepers" of an established art world or market segment (Becker 1982; Arora and Vermeylen 2012, p. 3). Expertise is a connecting factor between artists and dealers, auction houses, and their clients, and it is experts that produce the knowledge necessary to reduce the uncertainty characterizing the art market-uncertainty that seems to be proliferating online (Adelaar 2000). However, this uncertainty can be exploited, and value can be made or added in the online art auction market through the mediation of expertise.

Indeed, the art market is symptomatic of the rise of what social anthropologists Luc Boltanski and Arnaud Esquerre call an "enrichment economy." In Enrichment: A Critique of Commodities, they argue that an enrichment economy involves experts creating and shaping the identities and differences between objects as a way of establishing value (p. 46). In fact, Boltanski and Esquerre situate "value" as a fact that comes after "price"; they define the value of an object as "an arrangement for justifying a price" (p. 92). According to them, a reference to value is "relevant only insofar as it permits the prices of things to be criticized or justified" (p. 73). As such, the value of an object can never be stabilized once and for all, "rather it is the result of a process of valuation that belongs to the order of events rather than the order of facts" (p. 92). For Boltanski and Esquerre, the value of an object, thus, fundamentally depends on the very ways in which it is evaluated.

Contrary to the industrial economy which traditionally values newness and innovation above all else, in an enrichment economy, special attention is paid to the uniqueness of objects, the values of which may increase with time and parallel to the expert narratives that can be told about their heritage (p. 17). In fact, Boltanski and Esquerre show how processes of enrichment make use of narrative structures "in order to select, from the multiplicity of potentially relatable phenomena, the differences presented by the object in question that can be considered especially pertinent and that must therefore be singled out and highlighted in the discourses that accompany the object's circulation" (p. 45). A growing interest in so-called blue-chip artworks that are traded at exceptionally high prices 
and a flourishing luxury industry are cases in point (p. 19). For instance, the value of high-end artworks does not stem from their use-value, but from their position within a collection of art, historical relevance, and perhaps from their ability to be turned into an asset that generates a steady stream of income, such as when used as collateral against a loan to be reinvested and used for purposes of speculation (p. 43).

Boltanski and Esquerre identify what they call the "collection form" and the "asset form" as the dominant ways of creating value in the enrichment economy. In the "asset form", "a thing is a commodity transformed into money, treated as quasi-money, or treated as a substitute for money" (p. 241). Artworks are distinguished here based on their financial liquidity and the predictability of their commercial potential. Particularly, large auction houses, which widely publish the hammer prices of works of art, grant these works the status of "liquid assets", allowing them to serve as the virtual equivalent of money (p. 247). Moreover, the fact that a work is sold at a prominent auction house such as Sotheby's or Christie's in and of itself may increase the price of that object, which, in another transactional context, would perhaps have remained unsold or would, in any case, have only sold for a lower price (p. 244). According to Boltanski and Esquerre, the expansion of the secondary art market, the proliferation of online ranking lists and price indices for artists and artworks, as well as an increase in the convergence of the art world and the worlds of finance contribute to the significance of the asset form (p. 33); (also compare Birch and Muniesa 2020).

However, it is first and foremost in the collection form that Boltanski and Esquerre claim artworks acquire their value. According to them, in the collection form, value is added to objects through the stories constructed around them by highlighting distinctive features and creating a form of scarcity in relation to already existing collections. Boltanski and Esquerre further explain that the collection form calls upon the "memorial power" of objects; a power which is not immanent to these objects but rather a "socially attributed quality" (p. 192). For example, the physical proximity or presence of people or important moments in history may contribute to artworks' memorial power. In addition, the attribution of authorship has a strong influence on the memorial power of an object in the collection form, and in turn, on its price. If a work of art is first attributed to an old master painter and if expert research later shows that it is by a student employed in the master's studio, this can lead to a collapse of the memorial power while the materiality of the work remains unchanged (p. 192). Finally, in the collection form, copies of works of art are generally not accepted as legitimate and proof of authenticity is required. According to Boltanski and Esquerre, an object is considered authentic if authoritative expertise backs its origin and provenance (p. 181).

Boltanski and Esquerre emphasize that the collection form is not only aimed at collectors in the narrow sense of the word, but they see it as a way "to appreciate the value of things judged 'exceptional' by envisaging them from a point of view comparable to the one which a collector would consider them" (p. 194). This way of appreciation is a guiding principle in the "enrichment economy" and it is intrinsically linked to the art market, where the value of objects is directly proportional to their singularity and uniqueness. In fact, evaluations of artworks depend largely on the authority and legitimacy of experts and their expertise, and it is thus that we used recent economic sociological theory and Boltanski and Esquerre's anthropological theory of value and "enrichment" as lenses through which to analyze how expert narratives of origin, authenticity, and uniqueness are communicated online to affect an object's auction value in the case of online auctions at Bernaerts Auctioneers.

\section{Online Auctions and the Value of Expertise}

During the May 2020 online sale at Bernaerts Auctioneers, at the height of the first wave of the COVID-19 pandemic, some very expensive pieces were offered without the bidders having had the opportunity to physically inspect them. Initially, this caused some concern to the brothers Bernaerts, who, in addition to their roles as owners, also fulfill 
the roles of the auctioneer (Peter Bernaerts) and head of expertise (Christophe Bernaerts) within the auction house. However, the brothers reflected on a very successful sale and they indicated that the fact that there were few or no complaints about purchased pieces pleasantly surprised clients and auctioneers alike. According to Peter and Christophe Bernaerts, it is primarily the reputation they had built up in the previous years that makes their online auctions a success. In fact, they believe a good reputation and an already existing "name" to be a must in the online art auction market. They do, however, stress that "a good reputation comes on foot and goes on horseback", which is why they invest heavily in research and the mediation of their expertise (P. Bernaerts and C. Bernaerts, personal communication, 1 April 2021).

Indeed, following Boltanski and Esquerre, institutional authority plays an important role in creating value for an object at auction. If auction houses with a certain status sell an object, this contributes to the price the object will fetch (Boltanski and Esquerre 2020, p. 244). However, open online platforms challenge this transactional context, which, according to the sociological and anthropological literature, must be taken into account to make sense of value creation throughout auctions. In fact, with the rise of online platforms, such as, for example, the Catawiki website, which facilitates online auctions against the clock and where both private individuals and dealers can offer their works of art, memorabilia, and collectibles for a starting bid of EUR 1, many traditional auction houses, including Bernaerts Auctioneers, initially feared heavy competition.

The commissions on websites such as Catawiki are extremely low, and expert intervention is minimal. Therefore, one could perhaps argue that these websites organize online auctions as traditional neoclassical economists would imagine them-assuming that the mechanisms of supply and demand will do their work. However, Peter and Christophe Bernaerts argue that, in practice, websites such as Catawiki cause the middle price class of objects to level off. They claim that many objects from the traditional middle class achieve lower prices on these sites and a gap is created between a very low and very high price class, which, according to them, is one of the very reasons why, when this website emerged, the traditional auction houses were worried (P. Bernaerts and C. Bernaerts, personal communication, 1 April 2021).

However, after positive experiences of exclusively selling online during the COVID-19 pandemic, Peter and Christophe Bernaerts are now convinced that traditional auction houses like theirs-where experts research the objects offered for sale and promote them through various channels-are not actually threatened by Catawiki's business model. Bernaerts Auctioneers has found a workaround using Auction Mobility, Invaluable, and Drouotonline, or what Rachel Pownall describes as "auction marketplaces" (Pownall 2017, p. 31). These are platforms that only host authorized online auctions from traditional auction houses, but allow for users to follow multiple auctions simultaneously. For instance, Invaluable and Drouotonline collect bids as well as absentee bids from potential buyers on behalf of the auction houses, passing them through their software. Bernaerts Auctioneers' experience has long utilized these platforms alongside their physical auctions. Contrary to Catawiki, they allow traditional auction houses the provision of extra services, thereby maintaining their exclusive "gatekeeper" role and guaranteeing high-quality sales. In fact, the brothers Bernaerts note that their price segment has only increased since selling online.

This illustrates Boltanski's and Esquerre's theory of enrichment, where the creation of value begins before the auction starts. According to Boltanski and Esquerre, the prices that lots fetch depend largely on the expert narratives that are created about these particular objects, particularly regarding their authenticity and uniqueness. It is of great importance who creates these narratives, too. After all, these accounts are only considered legitimate if the credibility or reputation of the expert in question is accepted and trusted (Bonus and Ronte 1997; Beckert and Rossel 2013). Correspondingly, the creative efforts that Bernaerts made during the pandemic were mainly targeted at communicating its expertise to potential bidders and proving it as resilient in an exclusive online sales environment. 
One of the new channels through which Bernaerts achieves this is its online publication Prelude, which is integrated into its website, and which has effectively come to substitute its classic printed auction catalog. Another channel is social media, including Instagram.

In this study, we reflected on two examples of mediating expert knowledge about lots that Bernaerts Auctioneers offered at its April 2021 auction-a double portrait by the painter Geldorp Gortzius and a work by the painter Renee Guiette (each sold for EUR 26,000 and EUR 32,000 respectively). Central to our analysis was Boltanski's and Esquerre's collection form of value creation (Boltanski and Esquerre 2020, p. 192). Accordingly, we paid specific attention to the mediation of expert narratives supporting the memorial power of the lots, including their authenticity and uniqueness. For example, the proximity to important persons or events in history, the recognition of the worth of an object by institutions (p. 126), the known origin of an object (p. 181), or the presence of signatures play a crucial role in this.

When considering our first example, the expert narrative in Prelude on Gortzius' painting “Double portrait of Martin Hureau (1575-1630) and Margaretha de Groote (1590-1670), Cologne 1608", we noted that Elise Boutsen, Bernaerts Auctioneers' expert for old master paintings and her co-author Christophe Bernaerts, head of expertise at the auction house, paid attention to the fact that both portraits are "dated and monogrammed". In addition, Boutsen and Bernaerts traced the provenance of the work from the collection of Hureau and de Groote himself to the Le Grelle-Moretus family, whose grandchildren now offer the paintings for sale. In fact, the portraits are part of a thematic sale in which the entire art collection of this prominent Antwerp family goes under the hammer. In the view of Boltanski and Esquerre, both the presence of signatures and the ability to guarantee the authenticity of a work of art by naming all the links between the moment of production and the present contribute to the creation of value for a work of art (Boltanski and Esquerre 2020).

Once Boutsen and Bernaerts established the authenticity of the works, the experts switched to writing a narrative about the creation of the two portraits and the story behind the marriage of the depicted. These narratives contributed to the memorial power of the works. For example, it is told how "the young Martin Hureau is traveling to Cologne with a troubled mind to meet his fiancée from whom he only knows that she is rich but ugly" (Bernaerts Auctioneers 2021). This storyline was then substantiated by the reference to a plaintive letter by Hureau that it "is still kept in the Antwerp city Archives", a material proof. In a narrative tone, it was then stated,

The 33-year old groom was right about the wealth of his young bride. Margaretha de Groote was the daughter of Nicolaas de Groote (1549-1631), an important merchant in spices, textiles and luxury goods who established his business during the Antwerp Golden Age.

The fact that Margaretha de Groote was affiliated with an important merchant also contributes to the memorial power of the works. It is, after all, built on the physical proximity of objects to important events or persons in history (Boltanski and Esquerre 2020, p. 192).

Another point relates to the role of cultural institutions, as emphasized by Boltanski and Esquerre. According to them, institutions such as museums and universities are capable of conferring authority and legitimacy to the memorial power of an object, for instance, by including them in collections that cannot be sold (Boltanski and Esquerre 2020, p. 126). Accordingly, Bernaerts' Prelude concluded its description of these portraits by stating,

The Rijksmuseum in Amsterdam owns two family series by his hand, including two very similar portraits of Lucretia del Prado and her husband Jeremias Boudinois from 1610 (inv. SK-A-916 and SK-A-917).

In fact, the value of objects in established public museums is often seen as generally accepted. The visible resemblance, supported by photographs, between the portraits 
auctioned by Bernaerts and those hanging in the Rijksmuseum, contributes, in turn, to the creation of value for these works of art.

Bernaerts Auctioneers devoted a lot of space to the description and images of the two portraits by Gortzius on auction in Prelude. As stated earlier, Boltanski and Esquerre see the value of an object as the justification for its price. The detailed description can be seen as a way of justifying the estimation price (EUR 15,000-20,000). After all, the fact that two distinguished merchants from the seventeenth century are depicted here, and that one could substantiate this claim, added to the memorial power of the object. It rendered the portraits unique and, thus, more desirable to a potential buyer. By actively employing expert knowledge and disseminating narratives about origin and authenticity online, Bernaerts thus established the value of the lot and managed to fetch a price that substantially exceeded the initial indication of value.

Of course, similarly elaborate descriptions as those included in Prelude would also have been found in a traditional auction catalog. However, our participant observations indicated the resilience of expertise in an online setting. We witnessed how Bernaerts Auctioneers invest a lot of time and effort in incorporating intricate hyperlinks in Prelude. Through this particular form of online mediation, for instance, linking to the relevant pages on the website of the Rijksmuseum, the experts succeed in visualizing the similarities between works in a user-friendly manner. Other hyperlinks in Prelude lead visitors to the catalog of a previous Christie's sale and to the website of the Louvre, where similar objects (e.g., a chimneypiece after Pierre Phillippe Thormire) have been sold and exhibited. Ultimately, these links lend legitimacy to the expertise and allow associations to be made with major cultural institutions and other credible market actors, thus contributing to the value of the particular objects on sale.

Our second example is René Guiette's (1893-1976) painting "Composition with Maison Guiette, around 1928", in which Guiette depicted his house and studio designed by the famous architect Le Corbusier. To describe the painting, Bernaerts resorted to publishing in full a text by the art historical experts Siska Beele and Bob Daems, both working at the Royal Museum of Fine Arts in Antwerp and authorities in their fields. Prelude plays into establishing the memorial power as well as the uniqueness and authenticity of the painting featuring Beele and Daems, explaining,

René Guiette was captivated by the artistic innovations that were taking place at that time in Paris. As a supporter of the rigorous ideals of the art magazine L'Esprit Nouveau, he took an initiative that was considered revolutionary at the time: for the building of an atelier in Wilrijk, he called upon the modernist architect Le Corbusier (1883-1965).

Next to the experts' narrative about the special historical status of Guiette's house, Bernaerts also communicated about the recognition of LeCorbusier's architecture by heritage institutions. For instance, right before the auction of Guiette's painting, the restoration of the house, which is located in Populierenlaan in Antwerp, was subsidized with EUR 95,000 from the Flemish government. Bernaerts' swiftly exploited this news to generate attention for its auction of Guiette's painting in an Instagram post explaining how "Maison Guiette, the only preserved building by Le Corbusier on Belgian territory, lives up to the name of this modernist and cubist architect", and how it was for this reason that it won its place on the UNESCO World Heritage List in 2016. This listing and the recently granted subsidy are tantamount to recognizing the value of this house, according to Bernaerts. Its Instagram post emphasizes the structure's uniqueness as the only building by Le Corbusier in Belgium, aiming to establish the value of Guiette's painting too. Bernaerts Auctioneers also makes use of relevant hashtags under its social media posts, as in the case of Guiette's painting, when \#unescoworldheritage was used. This, again, offers the possibility of affiliating the work or the auction house with certain institutions, as well as attracting Instagram users who might find alternative ways to Bernaerts Auctioneers' account.

Further to the attention generated via social media about Guiette's house, additional narratives published in Prelude about his painting, again, focused mainly on establish- 
ing the artwork's memorial power, as well as its uniqueness and authenticity. Next to the traditional mentioning of the artist's signature and the painting's provenance, the historical significance to the painter and the proximity to the legendary architect of the depicted building contribute to this. In addition, the Flemish government's and UNESCO's recognition of "Maison Guiette" promotes this appreciation process, as they place similar emphases on historical relevance.

Ultimately, our examples show how Bernaerts Auctioneers considers expert knowledge essential to establishing the value of lots at online auctions. Through their use of various online formats, they seek to allow for a broader mediation of expertise compared to the classic auction catalog. In fact, for both of our examples, Bernaerts Auctioneers recorded videos in which a specialized expert explains the particular works of art. These videos, which are posted on the social media channels of Bernaerts Auctioneers and directly link to Prelude, constitute a virtual surrogate for a personal interaction with the trusted experts in question, who employ the format to highlight certain characteristic elements of the work and to show it from multiple angles. This is further enhanced by the inclusion of high-resolution photographs in Prelude so that potential buyers are able to thoroughly inspect an artwork from behind their screens. Last but not least, a chat function is permanently available in the bottom right corner of Bernaerts Auctioneers' website, representing approachability and imitating onsite personal conversation at the auction house.

In their creative online mediation of expertise during the COVID-19 pandemic, Bernaerts Auctioneers appears to have been quite successful. As in our examples, many of their lots have sold above the price indication. Moreover, it is striking that when the brothers Bernaerts compared their business figures for 2019 and 2020, there were noticeably fewer expenses in the year with COVID-19. They claim that this is partly due to fewer catalogs being printed and fewer casual staff needed for surveillance during the exhibition. Bernaerts also distinguishes between the traditional, well-attended exhibition weekends in the pre-COVID era and the exhibition weekends during 2020 (which, halfway into the pandemic, were allowed again under strict conditions and for a limited audience), concluding that the online format yielded real benefits. In fact, Peter and Christophe Bernaerts assert that by working by appointment only, they attracted more quality buyers to whom they could provide better service.

Looking back at our participant observation at Bernaerts Auctioneers, as well as considering the Bernaerts brothers' reflections on the performance of their auction house during the past year and during the COVID-19 pandemic, it is noteworthy that the number of online registered buyers during the crisis tripled compared to the previous year. In addition, the auction house sold $55-65 \%$ of their lots online in 2020. Peter and Christophe Bernaerts conclude that the COVID-19 pandemic has positively accelerated their digitization process. Previously, their attitude towards online auctions was characterized by reluctance, so as not to offend the regular (often elderly) clientele. Now, everyone had to jump on the online bandwagon if they still wanted to participate in the auctions. Because of the sanitary measures, there was simply no other choice.

In fact, when presented with the assumption that, due to what Georgina Adam describes as "testosterone-driven behavior", people would be more likely to bid in the auction room than online, Peter and Christophe Bernaerts state that, in their experience, this is not at all the case. In online auctions, they say, the game element of pushing the button and the associated thought of "am I going to make it or not" continues to play a prominent role. According to them, what used to happen in the auction room translates to the screen, and with online auctions, one equally runs the risk of being carried away "in the heat of the moment".

When asked how he experiences the lack of live social interaction in the auction room as an auctioneer, Peter Bernaerts admits that he of course sometimes has the experience of "crying in the wilderness" if there is no interest in a particular lot. Nevertheless, the same feeling overcomes him when there are people in the room, and he wonders aloud which of the two situations is the most annoying. He explains how his auction house tries to create 
a dramatic effect during online auctions, to get the bidders' adrenaline going. This is done, for example, by using multiple cameras in the auction room, with the telephone panel also regularly coming into view when bids are being made there.

In fact, Bernaerts Auctioneers does everything it can to reach its clients and the public online. During our participant observation, we witnessed many discussions among the auction house staff-about what attitude the auctioneer should adopt and how he can best address the online bidders to involve them in the auction, as well as how best to mediate relevant expertise, and apparently with good success; by now, Peter Bernaerts believes that a physical presence in the auction hall does not necessarily play a role in the bidding behavior of his customers and he considers it to be rather overestimated. In the wake of the COVID-19 pandemic, Bernaerts Auctioneers seems to have found effective ways to negotiate the value of artworks at auction and to influence their prices-all online.

\section{Conclusions}

Auctions are institutionalized social practices of managing the ambiguity and uncertainty of value by creating meaning and consensus. The value of an object on auction is not absolute but dependent on the context in which it is set. Online art auctions are no exception. In fact, based on recent economic sociological and social anthropological scholarship, and in contrast to neoclassical economics, we argue that the authority and legitimacy of, as well as the trust in experts and their expertise influences negotiations of value in markets of singularities, including art auctions online.

In this article, we presented our specific analysis on how exactly Bernaerts Auctioneers in Antwerp mediates its expertise in the wake of the forced transition to "online-only" sales during the COVID-19 pandemic. Our analysis shows how one of the largest Belgian auction houses creatively communicates expert narratives of origin, authenticity, and uniqueness online to establish the value, and ultimately to affect the price of its commissioned artworks. Aiming to allow its clients to bid better online in Belgium — to put it in a variation on the auction house's popular marketing slogan "Better in Belgium"-Bernaerts Auctioneers pursues online surrogates for live personal interactions. This illustrates how the establishment of the value of objects at auction and, correspondingly, their hammer price, extends beyond market principles of supply and demand. Ultimately, our interpretation of Bernaerts Auctioneers' creative ways of dealing with the challenges and opportunities posed by the pandemic thus speaks to the resilience and lasting value of practices of expertise and expert knowledge.

Author Contributions: S.K. conducted the qualitative research on which this article is based during her graduate studies at Maastricht University, when-academically supervised by C.R.—she was an intern at Bernaerts Auctioneers. All authors have contributed equally to the writing of this article. All authors have read and agreed to the published version of the manuscript.

Funding: This research received no external funding.

Institutional Review Board Statement: Not applicable.

Informed Consent Statement: Not applicable.

Data Availability Statement: Not applicable.

Conflicts of Interest: The authors declare no conflict of interest.

\section{References}

Adam, Georgina. 2014. Clicks vs. Bricks. In Big Bucks: The Explosion of the Art Market in the 21st Century. Edited by Georgina Adams. Farnham: Ashgate Publishing Ltd., pp. 117-28.

Adam, Georgina. 2018. Dark Side of the Boom. In The Excesses of the Art Market in the 21st Century. London: Lund Humphries Publishers Ltd.

Adelaar, Thomas. 2000. Electronic commerce and the implicaitons for market structure: The example of the art and antiques trade. Journal of Computer-mediated Communication 5: JCMC531. 
Adkins, Lisa, Melinda Cooper, and Martijn Konings. 2020. The Asset Economy: Property, Ownership and the New Logic of Inequality. Cambridge: Polity Press.

Arora, Payal, and Filip Vermeylen. 2012. The end of the art connoisseur? Experts and knowledge production in the visual arts in the digital age. Information and Communication Society 16: 194-214. [CrossRef]

ArtPrice. 2021. The Art Market in 2020. Available online: https:/ / www.artprice.com/artprice-reports/the-art-market-in-2020 (accessed on 31 August 2021).

Becker, Howard. 1982. Art Worlds. California: University of California Press.

Beckert, Jens, and Jörg Rossel. 2013. The Price of Art. Uncertainty and reputation in the art field. European Societies 15: 178-95. [CrossRef]

Bernaerts Auctioneers. 2021. Prelude: This Is Not a Catalogue. Bernaerts Auctioneers. Available online: https://www.bernaerts.eu/ nieuws.php?pid=327\&p=\&cat_id=\&search= (accessed on 31 August 2021).

Birch, Kean, and Fabian Muniesa. 2020. Assetization. In Turning Things into Assets in Technoscientific Capitalism. Cambridge: The MIT Press.

Boltanski, Luc, and Arnaud Esquerre. 2020. Enrichment: A Critique of Commodities. California: Polity Press.

Bonus, Holger, and Dieter Ronte. 1997. Credibility and Economic Value in the Visual Arts. Journal of Cultural Economics 21: 103-18. [CrossRef]

Hiscox. 2021. Hiscox Online Art Trade Report 2020. Hamilton: Hiscox, Available online: https:/ /www.hiscox.co.uk/online-art-tradereport (accessed on 31 August 2021).

Karpik, Lucien. 2010. Valuing the Unique: The Economics of Singularities. Princeton: Princeton University Press.

McAndrew, Claire. 2020. The Art Market 2020. Basel: Art Basel \& UBS.

McAndrew, Claire. 2021. The Art Market 2021. Basel: Art Basel \& UBS.

Mun-Desalle, Y-Jean. 2020. The Most Expensive Artworks Sold in 2020. Artsy. Available online: https:/ /www.artsy.net/series/expensiveartworks-sold-auction/artsy-editorial-expensive-artworks-sold-2020 (accessed on 31 August 2021).

Orléans, André. 2014. The Empire of Value: A New Foundation for Economics. California: The MIT Press.

Pownall, Rachel. 2017. Online Focus: TEFAF Art Market Report. Maastricht: The European Fine Art Foundation.

Rausch, Christophd, Léonie Bouwknegt, Jeroen Duijsens, and Frank Assendelft. 2021. 'Dirty money, pretty art'. Witwassen en ondermijning in tijden van financialisering van kunst. Justitiële Verkenningen. Trends in Kunstcriminaliteit 20: 28-40.

Sidorova, Elena. 2019. The Cyber Turn of the Contemporary Art Market. Arts 8: 84. [CrossRef]

Smith, Charles. 1989. Auctions: The Social Construction of Value. California: University of California Press.

Sotheby's. n.d. Record-Breaking Bidding in Sotheby's Auction of the Future. New York: Sotheby's. Available online: https: //www.sothebys.com/en/videos/record-breaking-bidding-in-sothebys-auction-of-the-future (accessed on 31 August 2021).

Sullivan, Paul. 2020. Auctions Are Crimped as the Pandemic Forces Them Online. The New York Times. Available online: https: //www.nytimes.com/2020/07/10/your-money/auctions-wealth-coronavirus.html (accessed on 31 August 2021).

Velthuis, Olav. 2007. Talking Prices: Symbolic Meanings of Prices on the Market for Contemporary Art. Princeton: Princeton University Press.

Velthuis, Olav. 2011. Damien's Dangerous Idea: Valuing Contemporary Art at Auction. In The Worth of Goods. Valuation and Pricing in the Economy. Edited by Jens Beckert and Patrik Aspers. Oxford: Oxford University Press, pp. 178-200.

Villa, Angelica. 2020. The Top 15 Most Expensive Artworks Sold at Auction in 2020. ARTnews. Available online: https://www.artnews. com/list/art-news/artists/most-expensive-works-sold-at-auction-1234579250/gerhard-richter-abstraktes-bild-649-2-1987/ (accessed on 31 August 2021). 